\title{
Towards an unsustainable urban development in post-war Sarajevo
}

\author{
Jordi Martín-Díaz \\ Department of Geography \\ University of Barcelona \\ Jordi Nofre \\ Interdisciplinary Centro of Social Sciences \\ New University of Lisbon \\ Marc Oliva \\ Centre of Geographical Studies. \\ University of Lisbon \\ Pedro Palma \\ Centre of Geographical Studies. \\ University of Lisbon
}

Martín-Díaz, J., Nofre, J., Oliva, M., \& Palma, P. (2015). Towards an unsustainable urban development in post-war Sarajevo. Area, 47(4), 376-385.doi: 10.1111/area.12175

\begin{abstract}
Sarajevo, the capital of Bosnia and Herzegovina, is located in a karst geomorphological environment. The topographical setting strongly inßuences the urban geographical distribution and urban develop-ment, as well as the sustainability policies implemented in the city. The incorporation of an environ-mental agenda and the focus on sustainable development have characterised urban planning in cities in Central and Eastern Europe that are transitioning from socialist to capitalist economic systems. Environ-mental policies in Sarajevo are dePned within the Sarajevo Canton Development Strategy developed under the supervision of international experts at the end of the three-and-a-half years of siege in December 1995, and this is expected to last until 2015. This paper argues that, despite the consensus achieved for developing Sarajevo through strategies aligned with European regulations for sustainability, the built environment of the city has moved in an increasingly unsustainable direction as a result of the need to deal with vulnerable groups in the population and the international policies that tend to promote a neoliberal urban development. The Prst section of analysis focuses on SarajevoÕ̃s existing particular geomorphological constraints on the development of a secure and sustainable built environment. The second section examines the increase in the geomorphological risks of new construction developed after the conßict in relation to the post-war and post-socialist urban processes.
\end{abstract}

Key words: Sarajevo, Bosnia and Herzegovina, post-socialist cities, geomorphology, urban sustainability, strategic planning 


\section{Introduction}

The geomorphological vulnerability of urban environments has been widely studied over recent decades from a broad range of perspectives (Gupta and Ahmad 1999; Huang and Mu 2000; Adeli and Khorshiddoust 2011; de Waele et al. 2011). Flash flooding has been identified as one of the major hazards in Mediterranean karst terrains that can cause significant damage to urban areas (Maréchal et al. 2008). For cities in Eastern and South Eastern European karst environments, several studies have focused on the impacts that geomorphological processes (namely, floods, slope processes, ground deformation and col-lapses) may have on new suburban areas (Stecchi et al. 2012; PapadopoulouVryniotia et al. 2013). However, the significant devastation produced by the recent floods of May 2014 in Bosnia and Herzegovina shows that these geomorphological risks need to be considered more seri-ously and assessed in a more effective way.

The geographic setting of many cities strongly affects population distribution in urban areas and the geomorphological risks to which these cities are exposed. This is the case for the area of Sarajevo, the capital of Bosnia and Herzegovina. The interactions between the urban environment and the geomorphology of this city have been poorly studied (e.g. Golobic and Cof 2010). In Sarajevo, the major urban processes that occurred after the end of the Bosnian War (1992-1995) have favoured the expansion of urban and suburban sprawl (Dematteis 1998; Champion 2001). This process was a result of the demographic pressure that emerged in the years immediately following the war, as well as of the neoliberal urban policies driven by international actors (Martín-Díaz 2014). The primary cause was the increasing demographic pressure driven by refugees and internally displaced persons, as outlined in the Dayton Peace Agreement. In this sense, new urban developments in Sarajevo and its suburban areas came up against the rugged geomorphological setting of the city, putting at risk the accomplishment of the environmental agenda, which were approved in line with European regulations for sustainability (Kanton Sarajevo 2000).

This paper identifies and examines those urban and suburban areas in Sarajevo that are potentially affected by some critical geomorphological risks, such as flooding and landslides that have arisen during the post-war period. The analysis of such urban geomorphological risks take into account the implementation of Sarajevo's environmental agenda and the very complex social, ethnic and political environment that has emerged after the Bosnian War. Despite the consensus reached for developing Sarajevo through strategies aligned with the European regulations for sustainability, the built environment of the city has increasingly moved in an unsustainable direction, on the one hand as a result of the need to deal with vulnerable population groups and, on the other hand, because of land liberalisation policies.

The paper is structured in two sections. The first section focuses on Sarajevo's existing geomorphological constraints on the development of a secure and sustainable built environment. The second section examines the increase in the geomorphological risks associated with new construction developed after the conflict and under the postwar/post-socialist processes. 


\section{Study area}

The Sarajevo Canton has a total area of $1276 \mathrm{~km} 2$ and a population of 438443 inhabitants (Federalni Zavod za Statistiku 2013), with a density of 343.37 inhabitants $/ \mathrm{km} 2$. The population is mainly concentrated in the four municipalities making up of the City of Sarajevo in a narrow urban corridor along the Miljacka River: Stari Grad, Centar, Novo Sarajevo and Novi Grad.

Sarajevo is 518 metres above sea level and sur-rounded by the Dinaric Alps, with elevations exceeding $2000 \mathrm{~m}$ nearby (Treskavica, $2088 \mathrm{~m}$; Bjelašnica, $2067 \mathrm{~m}$ ). This mountain range is formed by Secondary and Tertiary sedimentary rocks, mostly limestones and dolomites. Sarajevo is located in a depression drained by the Miljacka River running ENE to WSW. The source of the Miljacka River is located in a karst environment (Kadin Selo region) and down-valley this river drains the runoff from the mountains surrounding Sarajevo. As in other rivers with a Mediterranean climate influence, the maximum discharge of this river takes place between October and December. Furthermore, in only $15 \mathrm{~km}$, it drops more than $1000 \mathrm{~m}$ in altitude (7.3\% slope gradient). This potentially enhances erosion activity up-valley and mass wasting processes, together with the risk of flash floods in the Sarajevo area.

The local climate is characterised by a mid-European continental climatology with the maritime influence of the Mediterranean Sea. The air condensation flowing from the Adriatic Sea, when passing over the coastal mountain ranges, leads to almost $900 \mathrm{~mm}$ of precipitation a year, mostly concentrated in spring and autumn. The rough local topography can trigger intense rainfall events during these seasons, which may have severe impacts on settlements and infrastructures.

\section{Methods}

Fieldwork was carried out between April and July 2010 with the purpose of identifying the geomorphological risks of new urban construction developed during the post-war period in Sarajevo. Both suburbanisation and densification processes were identified and examined according to their geomorphological vulnerabilities. The second phase of the field research was conducted between July and December 2013 with the objective of analysing the urban development policies adopted in Sarajevo after the war. This task focused on examining the adoption of both new planning tools by local institutions and the role of international actors in the implementation of the liberal peace-building agenda. Technicians and managers from the main local and international organisations working on urban planning and development were consulted. These included institutions such as the Development Planning Institute of the Sarajevo Canton, the City Council and the Office of the High Representative, responsible for overseeing and implementing the civil aspects of the Dayton Peace Agreement.

In order to build a GIS-based model to consider the landslides and flooding risks in Sarajevo, two methodological approaches were performed using GIS software (ArcGIS 10.1). The first was the delineation of the potential areas under water in a scenario in 
which the river level rises $2.5 \mathrm{~m}$. This corresponds with the maximum level reached by the Miljacka River during the flood event of May 2014 (Sarajevo Times 2014), the worst floods in the region in more than a century (Agencies 2014). This spatial analysis focused on the elevation differences between the river level and the surrounding areas. The second approach comprised the creation of a slope surface using the spatial analyst tools provided in the ArcGIS software. However, there was a significant lack of data from local and regional institutions to help generate an accurate Digital Elevation Model of the area. Despite this constraint, maps were produced with the elevation data available from international data sources at a resolution of $30 \mathrm{~m}$. Data were provided by the Advanced Spaceborne Thermal Emission and Reflection Radiometer (ASTER 2011), used in the elaboration of geomorphological maps (Kääb et al. 2003; Kamp et al. 2005). Figure 1 shows the location of Sarajevo in context.

\section{INSERT HERE. Figure 1. (a) Location of Sarajevo in Europe; (b) in the context of Bosnia; (c) aerial} image of the city

\section{Geomorphological implications for the urban setting in contemporary Sarajevo}

Sarajevo is located in a sedimentary catchment at elevations of 500-600 m, with limestone massif sreaching1000-1500 m encircling the city. The Miljacka and Bosna Rivers drain the hydrographic basin of Sarajevo-Zenica, which opened in the Tertiary period (Hrvatovic 2005). The infill of the Sarajevo plain is comprised of Quaternary sediments overlying the basal rocks of Miocene age. As in other extensive parts of the Balkan region, the regional setting is characterised by the wide-spread distribution of karst landforms. The contact between carbonaceous materials (limestones) and water (from rainfall, runoff or groundwater) initiates the diss-lution of the original bedrock (Jennings 1985). In the region of Sarajevo, karstification processes are very intense and have resulted in a wide range of karst-related geomorphological features.

Sarajevo's basin is flanked by a series of stepped ridges following the fault system (Hrvatovic' 2005). The depressions enclosed by these mountain steps make up areas with internal drainage systems known in karst environments as poljes (Sweeting 1973). Their dimensions vary from decametric to kilometric size. Stretching between these mountains, there is the elongated alluvial plain in which Sarajevo is located. In addition, on the floodplain there are also other karst landforms of metric or decametric size, such as the dolines.

In Sarajevo, most of these landforms are hidden by urban constructions. However, the local toponymy provides evidence of the wide distribution of karst landforms in the area. Dolina Street and places like Bijelo Polje, Skrbino Polje, Lasicko Polje or Grlicko Polje confirm the karst context in which the city is located. In this sense, it should be noted that, in the Bosnian/Croatian/Serbian language, the polysemic term 'polje' is used both to describe the geomorphological unit as well as the field areas, which reflects the close relationship between the landform and the landscape.

The Miljacka River flows along the main faults in the area before joining the Bosna River. After crossing a steep calcareous gorge at the eastern limit of Sarajevo, the river suddenly turns to the left, meandering when entering the city, where it gradually opens, forming an elongated alluvial plain parallel to the bed of the river. The contact between the basin and the surrounding relief is pronounced, especially on the left bank of the Miljacka, where the escarpment is steeper. By contrast, the slopes on the right side are more gentle. 
However, the present-day distribution of urban settlements is widespread on both slopes. Lithology and mountainous terrain no doubt affect the geomorphological setting and, in turn, have profound implications on the distribution of the population along the Miljacka valley. Showing a lower population density than in the flat valley bottom, the houses on the hillsides are distributed upslope in sequential steps, most of them as a result of the rapid urban development that occurred after the war.

On the banks of the Miljacka River, sediments were deposited during floods over the last millennia, contributing to the fertility of the soil, which historically has favoured agricultural activities. However, the expansion of the city and the higher frequency and larger magnitude of the floods during the 18th century in the Balkan region (Wanner et al. 2000; Xoplaki et al. 2001) led to the chanalisation of the Miljacka River during the Austro-Hungarian administration to mitigate the damage caused by floods (Donia 2006). The system, which still exists today, consists of a series of steps that reduce flow velocity and sediment transport capacity. The margins of the river were subsequently substituted by urbanised areas that currently are being renewed with new central tertiary and residential areas.

In mid-May 2014, major floods occurred in Sarajevo, causing severe damage to equipment, infrastructure and housing (Federalna Novinska Agencija 2014a 2014b). The impact of the floods was larger in the western out-skirts of the city, where the Miljacka and Željeznica tributaries converge with the Bosna River, flooding an extensive area of the Ilidža municipality. In addition, several landslides took place on the northern edge of the city (Jukic' 2014a). This extreme rainfall event primarily damaged the urban and rural areas in northern Bosnia. Between 14 and 16 May, across the whole country, there were up to 3000 landslides; 27 people died and 100000 buildings were destroyed or damaged (Agencies 2014; Jukic' 2014b).

\section{Increasing the geomorphological risks of the built environment}

Percolation water processes through bedrock are very intense in karst regions and may reach between 30 per cent and 40 per cent of the total annual rainfall (de Vries and Simmers 2002; Zagana et al. 2007). Percolation is especially significant in Mediterranean karst environ-ments (Lange et al. 2010; Hartmann 2012), where heavy precipitation can occur overs hort-time periods and water flows suddenly through the bedrock to lower areas. This may cause flash floods, especially when recent rainfall saturates the aquifer before the storm and increases and runoff (Wittenberg et al. 2007; Fleury et al. 2013). This is what happened between 14 and 16 May 2014 in Bosnia and Herzegovina. Following several weeks of heavy rain in the Balkan region, an extremely active lowpressure system named Tamara (Alert World Wide 2014) resulted in high precipitation and generated major floods, which affected Sarajevo. This extreme rainfall event, together with the karst lithology of the area and the unstable nature of the soils in Sarajevo and its surroundings (Golobic and Cof 2010), resulted in significant damage to settlements and infrastructure Similar to other areas of the country, in the area of Sarajevo many built environments are exposed to these geomorphological risks. Actually, the surface area potentially affected by geomorphological risks has increased in the last two decades as a consequence of urban sprawl, triggered by the arrival of refugees and internally dis-placed persons in Sarajevo after the war. The magnitude of this urban and demographic challenge is reflected in the fact that forced displacements then represented the largest refugee crisis in Europe since the Second World War (Hitchcock 2003); about 
half of the 4.4 million Bosnian population were displaced during the conflict (UNHCR 1999).

The Development Planning Institute of Sarajevo anticipated the wave of returns and expected urban sprawl by modifying the regulatory regime, managing urban development in the neighbourhoods with higher slope gradients. Regulation plans became mandatory to urbanise the slope areas, raising legal and procedural requirements for new construction, while guaranteeing the provision of basic services. The decision indicated the desire of local authorities to rationally plan for the urban sprawl foreseen in the city after the war.

Once the Office of the High Representative was empowered in December 1997 to invigorate the implementation of the Dayton Peace Agreement, it quickly focused on Annex 7 of the Agreement, which granted all refugees and displaced persons the right to freely return to their homes of origin. Sarajevo became one of the most intervened cities in all of Bosnia and Herzegovina in order to rebuild a multi-ethnic capital.1 The Sarajevo Declaration set out a comprehensive approach in February 1998, aiming to promote returns and make such urban and demographic processes sustainable (Office of the High Representative 1998). The subsequent removal of the discriminative housing legislation favoured the mass return of refugees and internally displaced persons.

The process of housing repossession led to the eviction of those internally displaced persons who had sheltered in Sarajevo during the war. The reluctance of many of them to return to areas controlled by other ethnic groups, either Serbs or Croats, triggered a wave of illegal housing construction in the late 1990s, which mainly involved build-ing extra floors on existing buildings or new single detached dwellings in the suburbs. The consequent sprawl in high-gradient sectors, regulated by the Urban Plan of 1986, was resumed after the war in some areas. This occurred in areas with steep slopes and high geomorphological risk, such as in the neighbourhoods of Aneks, Pofalic'i and Vraca.2 However, this post-war urban sprawl had a very different nature and meaning since most of the new single family dwellings were a consequence of formerly forced displacements (Cengic' 2011).

In these steep neighbourhoods, the topography of the superficial material and the hydrogeological character of the bedrock affect slope instability (Vierrether 2013). In some instances landslides have been periodically generated by illegal construction and the development of poor-quality infrastructure, such as sewers and river/stream chanalisation (Federalna Novinska Agencija 2014c). More specifically, a total of 816 landslides have been registered by the cantonal authorities in Sarajevo between 2000 and early 2014, with 523 in the four central municipalities (see Figures 2 and 3). There were 205 landslides considered as very dangerous, while the cost of restoring 123 landslides was 26 million KM (about €13.4 million) until January 2014 (Kanton Sarajevo 2014). During the floods of May 2014, landslides occurred mainly in the municipality of Vogošc'a (Federalna Novinska Agencija 2014c).

Despite the increase in planning regulations for the most vulnerable areas, the Development Planning Institute of Sarajevo estimates that illegal constructions completed during the post-war period totaled between 25000 and 50000 units in the area of Sarajevo.3 This urban sprawl in vulnerable sites, as the result of the convergence of the demographic pressure in an area con-strained by the geomorphology, undermined the 
urban development strategy of Sarajevo, as approved until the year 2015 (Kanton Sarajevo 2000). The introduction of strategic urban planning in European post-socialist cities must be seen as a response to the decline of comprehensive plans (Maier 1994; Tsenkova 2007). This strategic urban plan contains strong environmental rhetoric, following the European Union Action Plan 'Towards Sustain-ability', i.e. the Fifth Environmental Action Programme published by the European Commission in order to implement Agenda 21 (European Commission 1993).

The importance of the environmentally friendly visions for the urban development of Sarajevo (see Kanton Sarajevo 2000, 7) showed a desire to improve the existing environmental conditions. In fact, some of them, such as air pollution, had been improved as a consequence of the economic downturn of the late 1980s and the reduction of industrial activity during the war (Majstorovic et al. 2006). However, the development strategy adopted by the City Council of Sarajevo was not embedded in planning legislation. Moreover, the actualisation of the Urban Plan was limited, including only some of the visions of the plan, such as the creation of a real estate market, the construction of temples or the development of new cemeteries. 4

INSERT HERE. Figure 2. Landslides in Sarajevo and its surroundings over the last few years

Source: Development Planning Institute of the Sarajevo Canton (Kanton Sarajevo 2014)

In the context in which ethno-national parties aimed at consolidating ethnic territorialisation after the war (Toal and Dahlman 2006), the Office of the High Representative supervised land allocations during the period 1999- 2003 (Office of the High Representative 1999 2000). It was in May 2003 that the High Representative enacted the Law on Construction Land, moving land management back to the municipalities by dividing the socially owned construction land into state owned and private land on the basis of whether it had already been developed by a private actor or not (Williams 2013). The new law was a significant step in the efforts of international actors to create a real estate market, which had started three years before when the United States Agency for International Development was asked to analyse the status of real estate in Bosnia and Herzegovina, while recommending its reform (Rabenshort 2000). The convergence of urban policies, moving land into privatisation and policies pursuing economic liberalisation, produced a real estate bubble in the city 10 years after the end of the war.

However, many of these new urban projects have been developed in areas with high geomorphological risk. As shown by recent floods, several weeks of intense rainfall had saturated the calcareous aquifer of the Miljacka catchment, and the storm in May 2014 resulted in inundation of parts of the floodplain. Floodplain canalisation of the Miljacka contained most of the floodwater within central Sarajevo and only the margins of the river were flooded in flat area at the confluence with the Bosna River. The pressure on the margins of the Miljacka has increased since 2005, when a significant number of the new major urban projects built during the post-war period were developed on the alluvial floodplain of the river. This urban densification has thus increased the risk of floods affecting properties since several of the projects are located in the most flood-prone areas (Figure 4).

INSERT HERE. Figure 3 Areas with slope gradients above $20^{\circ}$ with the distribution of the new post-war urban projects as well as the landslides shown in Figure 2 (for further information about post-war urban projects see Martín-Díaz (2014, 311-12)) 
INSERT HERE. Figure 4. The post-war urban projects and potential flood-prone areas in a $2.5 \mathrm{~m}$ scenario, the level reached by the Miljacka River in mid-May 2014

This is the case of the Central Business District in the Marijin Dvor area and the Bulevard Meše Selimovic'a, where the development of new office buildings and commercial property, some of them illegally constructed, 5 have played a central role in urban restructuring and the spatial reorganisation of Sarajevo (Martín-Díaz 2014). This process of urban densification has been occurring primarily in the central and western neighbourhoods of Sarajevo, emerging during the socialist regime. The urban structures inherited from the socialist period have thus been reshaped under neoliberal forms of planning and development (Harvey 1989; Brenner and Theodore 2005; Tasan-Kok 2012). These developments have been eroding a sustainable feature of urbanism predominant in Central and Eastern Europe's cities, which had urban structures that were generally more environmentally friendly and sustainable than capitalist urban forms (Hirt and Stanilov 2009), being more compact and with more green spaces (French and Hamilton 1979; Szelenyi 1996).

\section{Conclusions}

The geomorphological context of the central areas of Sarajevo in the Miljacka valley has influenced the historical urban development of the city. The high demographic pressure on Sarajevo in the years following the Bosnian war (1992-1995) added another layer of complexity to the management of urban development. Anticipating the potentially significant return of refugees and internally displaced persons to the city, the Development Planning Institute increased the regulation required on the slopes to control its urban growth. The approval of regulation plans was thus aimed at providing basic services for a safe environment for people in precarious situations after the conflict, despite the poor environment of the higher gradient areas of the city. The construction of housing on these sites has increased the existing geomorphological risks, as shown by the significant number of landslides and the costs of restoration since the early 2000s. Further-more, policies implemented by international actors had significant environmental implications in moving the built environment in Sarajevo further along a long-term unsustainable direction. Land liberalisation policies led to an urban densification in central Sarajevo with enhanced urban sprawl in the surroundings of the city.

The recent extreme rainfall events that occurred in mid-May 2014 confirm the unsustainable nature of highly densified urban areas as well as in new suburban neighbourhoods located on steep slopes and floodplain areas of Sarajevo (e.g. Ilidža). Hence, along with the poor translation of the environmental visions into the rest of the planning hierarchy, both the creation of a real estate market and post-war demographic pressures have under-mined the foundations of the sustainable development agenda in Sarajevo. In vulnerable geomorphological urban settlements the elaboration and implementation of a comprehensive sustainable strategy for urban development must be seen as a priority, even though it deals with complex social and urban processes. In this sense, the proximity of the ending of the Sarajevo Canton Development Strategy and the Urban Plan in 2015 is a great opportunity to develop a more balanced social and environmentally sustainable strategy, taking into account not only the particular geomorphological setting of Sarajevo, but also its political, socioeconomic and symbolic specificities. 


\section{Acknowledgements}

This research has been financially supported by the Spanish Ministry of Education, the Portuguese Science Foundation and the AXA Research Fund. The authors would also like to thank the supervision and support from Dr Nihad Cengic' (University of Sarajevo) and Prof. Dr Carles Carreras (University of Barcelona), as well as the valuable comments of the reviewers.

\section{Notes}

1. This policy contrasted with the passivity of the international actors in the political and military field during the episodes of ethnic cleansing carried out during the war.

2. Suburbanisation on the slopes, mainly illegally developed, was inherited from the socialist period due to the housing shortage (Topham 1990). It was actually a concern for local authorities in the 1970s, when the programme for 'Rehabilitation of housing area on the slopes of the city' was launched to tackle the development in those areas considered a potential threat to the overall development of Sarajevo (Cengic' 2011).

3. Official data will not be available until the publication of the first Census since the independence of Bosnia and Herzegovina in 1992, which took place in October 2013.

4. Anonymous technician of the Development Planning Institute.

5. Anonymous technicians of the Development Planning Institute and the City Council.

\section{References}

Adeli Z and Khorshiddoust A 2011 Application of geomorphology in urban planning: case study in landfill site selection Procedia Social and Behavioral Sciences $19662-7$

Agencies 2014 Death toll rises to 43 in Serbia and Bosnia floods. The Telegraph 18 May 2014

Alert World Wide 2014 Balkan floods (http://alert.airworldwide.com/EventSummary.aspx $? \mathrm{e}=743 \& \mathrm{tp}=31 \& \mathrm{c}=1) \quad$ Accessed 15 October 2014

ASTER 2011 ASTER Global Digital Elevation Model Ministry of Economy, Trade, and Industry (METI) of Japan, United States National Aeronautics and Space Administration (NASA) (http:// gdem.ersdac.jspacesystems.or.jp/) Accessed 15 October 2014

Brenner N and Theodore N 2005 Neoliberalism and the urban condition City 9 101-7

Cengic' N 2011 Remodelling urban meaning Đ the Sarajevo case 4th International Conference on Hazards and Modern Heritage (CICOP), Sarajevo 
Champion T 2001 Urbanization, suburbanization, counter urbanization and reurbanization in Paddison R ed Handbook of urban studies Sage, London 14361

De Vries J J and Simmers I 2002 Groundwater recharge: an overview of processes and challenges Hydrogeology Journal 10 5-17

De Waele J, Gutiérrez F, Parise M and Plan L 2011 Geomorphology and natural hazards in karst areas: a review Geomorphology 134 1-8

Dematteis G 1998 Suburbanización y periurbanización. Ciudades anglosajonas y ciudades latinas in Monclu J ed La ciudad dispersa: Suburbanizaci-n y nuevas periferias Centre de Cultura Contemporànea de Barcelona, Barcelona 17-33

Donia R 2006 Sarajevo: a biography Hurst \& Company, London European Commission 1993 Towards sustainability Official. Journal of the European Communities No C 1385

Federalna Novinska Agencija 2014a Obrušilo se korito Miljacke kod mosta C «umurija Federalna Novinska Agencija 15 May 2014

Federalna Novinska Agencija 2014b Water pumped out from FBiH parliament building Sarajevo Federalna Novinska Agencija 16 May 2014

Federalna Novinska Agencija 2014c Mještani naselja Svrake prije tri godine bili su upozoreni na klizište! Federalna Novinska Agencija 21 May 2014

Federalni Zavod za Statistiku 2013 Census of population, house-holds and dwellings in $\mathrm{BiH}$, preliminary results by municipali-ties in the FBiH Statistical Bulletin 195

Fleury P, Maréchal J C and Ladouche B 2013 Karst flash-flood forecasting in the city of Nîmes (southern France) Engineering Geology 164 26-35

French R A and Hamilton F E 1979 The socialist city: spatial structure and urban policy John Wiley \& Sons, New York

Golobic M and Cof A 2010 Knowledge support for planning in transition - spatial vulnerability analysis for Canton Sarajevo (http://www.kolleg.loel.hsanhalt.de/landschaftsinformatik/ 436.html) Accessed 25 July 2014

Gupta A and Ahmad R 1999 Geomorphology and the urban tropics: building an interface between research and usage Geomorphology 31 133-49

Hartmann A, Kralik M, Humer F, Lange J and Weiler M 2012 Identification of a karst system's intrinsic hydrodynamic param-eters, upscaling from a single springs to the whole aquifer Environmental Earth Sciences 65 2377-89 
Harvey D 1989 From managerial to entrepreneuralism: the trans-formation in urban governance in late capitalism GeograPska Annaler 71 3-17

Hirt S and Stanilov K 2009 Twenty years of transition: the evolu-tion of urban planning in Eastern Europe and the former Soviet Union: 1989Đ2009 UN Habitat, Nairobi

Hitchcock W I 2003 The struggle for Europe: the turbulent history of a divided continent $1945 Đ 2002$ Doubleday, Ontario

Hrvatovic' H 2005 Geological guidebook through Bosnia and Herzegovina Geological Survey of Bosnia and Herzegovina, Sarajevo 156

Huang J and Mu G 2000 Urban geomorphology Progress in Physical Geography 24 4512

Jennings J N 1985 Karst geomorphology Basil Blackwell, Oxford Jukic' E 2014a Bosnia flooding causes landslides, destroys homes. BIRN Sarajevo 15 May 2014

Jukic' E 2014b Bosnia hopeful ahead of donors conference BIRN Sarajevo 15 July 2014

Kääb A, Huggel C, Paul F, Wessels R, Raup B, Kieffer H and

Kargel J S 2003 Glacier monitoring from ASTER imagery. Accu-racy and applications EARSeL eProceedings 2 Đ Observing our cryosphere from space 43-53

Kamp U, Bolch T and Olsenholler J 2005 Geomorphometry of Cerro Sillajhuay, Chile/Bolivia: comparison of DEMs derived from ASTER remote sensing data and contour maps Geocarto International 20 23-34

Kanton Sarajevo 2000 Sarajevo development strategy until the year 2015 Ministry of Reconstruction, Development and Envi-ronmental Protection, Sarajevo

Kanton Sarajevo 2014 Sanacija klizišta na podrucÿ ju Kantona Sara-jevo Zavod za izgradnju Kantona Sarajevo (http://zik.ks.gov.ba/ sanacija-klizi\%C5\%A1ta) Accessed 24 October 2014

Lange J, Arbel Y, Grodek T and Greenbaum N 2010 Water percolation process studies in a Mediterranean karst Hydrologi-cal Processess 24 1866-79

Maier K 1994 Planning and education in planning in the Czech Republic Journal of Planning Education and Research 13 263-9 Majstorovic Z, Tais M, Voloder M and Zulum D 2006 The cor-relation between air pollution and air temperature in Sarajevo Valley (1975Đ2006) Federal Hydro Meteorological Institute, Sarajevo

Maréchal J C, Ladouche B and Dörfliger N 2008 Karst flash flooding in a Mediterranean karst, the example of Fontaine de Nimes Engineering Geology 99 138-46

Martín-Díaz J 2014 Urban restructuring in post-war contexts: the Sarajevo case Hungarian Geographical Bulletin 63 303-17 Office of the High Representative 
1998 Sarajevo declaration and implementation (http://www.ohr.int/ohrdept/rrtf/key-docs/sa-

docs/) Accessed 25 April 2014

Office of the High Representative 1999 Decision extending until 30 June 2000 the decision on certain types of socially-owned land (http://www.ohr.int/decisions/plipdec/default.asp?content_id=210) Accessed 25 April 2014

Office of the High Representative 2000 Decision on re-allocation of socially owned land, superseding the 26 May 1999 and 30 December 1999 decisions (http://www.ohr.int/ decisions/plipdec/default.asp?content_id=213) Accessed 25 April 2014

Papadopoulou-Vryniotia K, Bathrellos G D, Skilodimoua H, Kavirisb G and Makropoulos K 2013 Karst collapse suscepti-bility mapping considering peak ground acceleration in a rapidly growing urban area Engineering Geology 158 $77-88$

Rabenshort C S 2000 The real estate market in Bosnia-Herzegovina: current status and recommendations for reform USAID, Sarajevo

Sarajevo Times 2014 Two and a half meter is Miljacka's water level FENA 14 May 2014

Stecchi F, Mancini F, Ceppi C and Gabbianelli G 2012 Vulner-ability to ground deformation phenomena in the city of Tuzla $(\mathrm{BiH})$ : a GIS and multicriteria approach Natural Hazards 64 2153-65

Sweeting M M 1973 Karst landforms Macmillan, London Szelenyi I 1996 Cities under socialism - and after in Andrusz G,

Harloe M and Szelenyi I eds Cities after socialism Blackwell, Oxford 286-317

Tasan-Kok T 2012 Introduction: Contradictions of neoliberal urban planning in TasanKok $\mathrm{T}$ and Gaeten $\mathrm{G}$ eds Contradic-tions of neoliberal urban planning. Cities, policies and politics Springer, New York 1-19

Toal G and Dahlman C 2006 The 'West Bank of the Drina': land allocation and ethnic engineering in Republika Srpska Transactions Institute of British Geographers $31304-22$

Topham S 1990 Housing policy in Yugoslavia in Sillience J ed Housing policies in Eastern Europe and the Soviet Union Routledge, New York 6-57

Tsenkova S 2007 Urban futures: strategic planning in post-socialist Europe in Stanilov K ed The post-socialist city. Urban form and space transformations in Central and Eastern Europe after socialism Springer, Dordrecht 447-72

UNHCR 1999 UNHCR global appeal 1999 Đ Bosnia and Herze-govina 
UNHCR Fundraising Reports (http://www.unhcr.org/ 3eaff43e9.html) Accessed 20 April 2014

Vierrether C B 2013 Urban development in karst and collapse-prone geologic environments Carbonates and Evaporites 28 23-9

Wanner H, Holzhauser H, Pfister C and Zumbühl H 2000 Interannual to century scale climate variability in the European Alps Erdkunde 54 62-9

Williams R 2013 Post-conflict land tenure issues in Bosnia: pri-vatization and the politics of reintegration the displaced in Unruh $\mathrm{J}$ and Williams $\mathrm{R}$ eds Land and postconßict peacebuilding Routledge, New York 145-76

Wittenberg L, Kutiel H, Greenbaum N and Inbar M 2007 Short-term changes in the magnitude, frequency and temporal distri-bution of floods in the Eastern Mediterranean region during the last 45 years - Nahal Oren, Mt. Carmel, Israel Geomorphology 84 181-91

Xoplaki E, Maheras P and Luterbacher J 2001 Variability of climate in meridional Balkans during the periods 1675-1715 and 1780-1830 and its impact on human life Climatic Change 48 581-615

Zagana E, Kuells C, Udluft P and Constantinou C 2007 Methods of groundwater recharge estimation in Eastern Mediterranean. Part I: a water balance model application in Greece, Cyprus and Jordan Hydrological Processes 21 2405-14 